\title{
Theoretical Application of Decision Support System in Petroleum Contaminated Ogoniland in South-Southern Nigeria
}

\section{Arinze Emmanuel Emeka*}

Department of Civil Engineering, Michael Okpara University of Agriculture, Umudike, Abia State, Nigeria

\begin{abstract}
Land is an indispensable natural resource made up of soil and groundwater, both of which have many functions for which we depend on, support of agricultural activities, engineering structures, portable water for domestic and industrial use as well as sustenance of flora and fauna in order to maintain favorable ecosystem. Contaminants in land pose a number of threats to public health and the environment; other natural resources; and have detrimental effects on property such as buildings, crops and live stocks. The most effective method of dealing with these contaminants is to cleaning up and returning the sites to beneficial use. The cleanup process involves making a choice from amongst competing remediation methods, where the wrong choice may have disastrous social, economic and environmental impact. This work presents the development of a Decision Support System via thorough literature survey. The Developed DSS was applied to petroleum contaminated site in Ogoniland South-East Nigeria. Finally, Air sparging, phyto-remediation and soil vapour extraction methods were systematically recommended.
\end{abstract}

Keywords: Decision support system; Petroleum; Contaminated land; Remediation

\section{Introduction}

Land is a limited resource that is increasingly getting polluted as a result of land contamination. Land is made up of soil and groundwater both of which have numerous functions for which humanity depend on, including provision of food and water, supporting shelter, natural flood defence, waste containment, maintaining natural cycles etc. Contaminants in land pose a number of threats to public health and ecosystem and have detrimental effects on lives and properties [1,2].

Petroleum hydrocarbon contaminants are amongst the most commonly occurring at contaminated sites. According to the European Environmental Agency (EEA) approximately 14.1 percent of identified contaminated lands in its countries are cause by the oil industry, with heavy metals, mineral oils and hydrocarbon contaminants constituting approximately $90 \%$ percent of the total contaminants found on sites [3]. According to available statistics, in the last 30 years more than 400,000 tons of oil have spilled into the creeks and soils of southern Nigeria. About $70 \%$ of the oil has not been cleaned basically because of inefficient cleaning or remediation method, ERA 2010. Figure 1 shows some contaminated sites in Ogoniland South Nigeria. The clean-up process involves making a choice from amongst competing remediation methods, where the wrong choice may aggravate the problem resulting to disastrous social, economic and/or environmental negative impact [1-8].

Contaminated land management is therefore much complex than the selection and implementation of removal solutions, and requires extensive data collection and analysis at huge cost and effort [2]. The need for decision support in contaminated land management decision making has long been widely recognised [4], and in recent years a large number of Decision Support System (DSS) have been developed. Nigeria is ploughed by numerous oil spills. The United Nations Environmental Programme (UNEP) announced that oil firms contaminated a 1,000 sq $\mathrm{km}$ (386 sq miles) area of Ogoniland, in the Niger delta with disastrous consequences for human health and wild life. Ogoniland is just a representative of many southern part of Nigeria that are contaminated [5]. The three-year investigation of UNEP discovered that; i. Heavy contamination of land and underground water causes, sometime more than 40 years after oil was spilled.

ii. Soil contamination is located more than five metres deep in many areas studied.

iii. Most of the spill site oil firms claimed to have cleaned are still highly contaminated.

iv. The UNEP report also cited lack of adequate remediation procedure or institutional framework and lack of trained manpower in government supervisory agencies as another

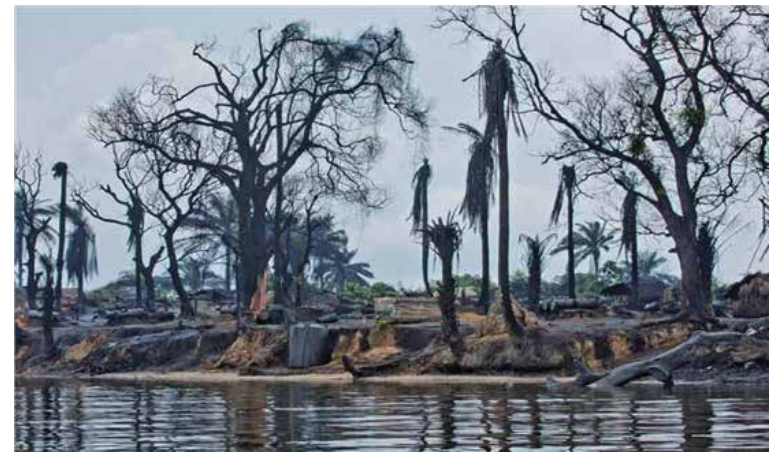

Figure 1a: The cumulative impact of artisanal refining puts significant environmental pressure on Ogoniland.

"Corresponding author: Arinze Emmanuel Emeka, Department of Civil Engineering, Michael Okpara University of Agriculture, Umudike, Abia State Nigeria, Tel: +2348188388313; E-mail: emmanuel.arinze@mouau.edu.ng

Received June 28, 2016; Accepted August 30, 2016; Published September 08 2016

Citation: Emeka AE (2016) Theoretical Application of Decision Support System in Petroleum Contaminated Ogoniland in South-Southern Nigeria. J Pet Environ Biotechnol 7: 303. doi: 10.4172/2157-7463.1000303

Copyright: (c) 2016 Emeka AE. This is an open-access article distributed under the terms of the Creative Commons Attribution License, which permits unrestricted use, distribution, and reproduction in any medium, provided the original author and source are credited. 
Citation: Emeka AE (2016) Theoretical Application of Decision Support System in Petroleum Contaminated Ogoniland in South-Southern Nigeria. J Pet Environ Biotechnol 7: 303. doi: 10.4172/2157-7463.1000303

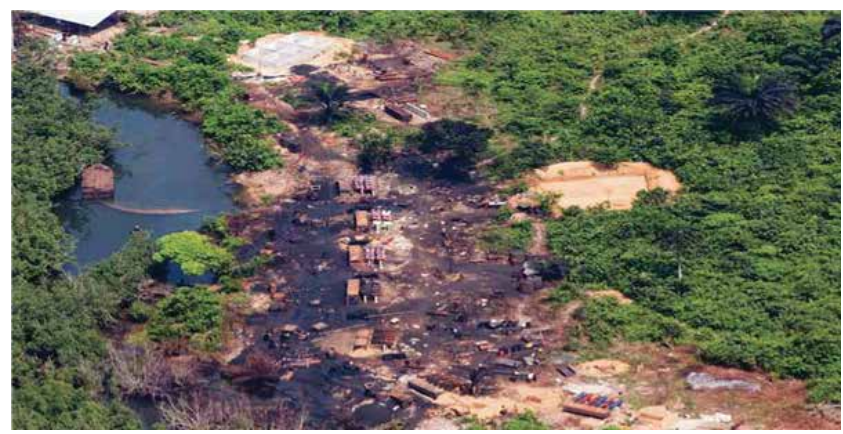

Figure 1b: Aerial view of artisanal refining site (Bodo West, Bonny LGA)

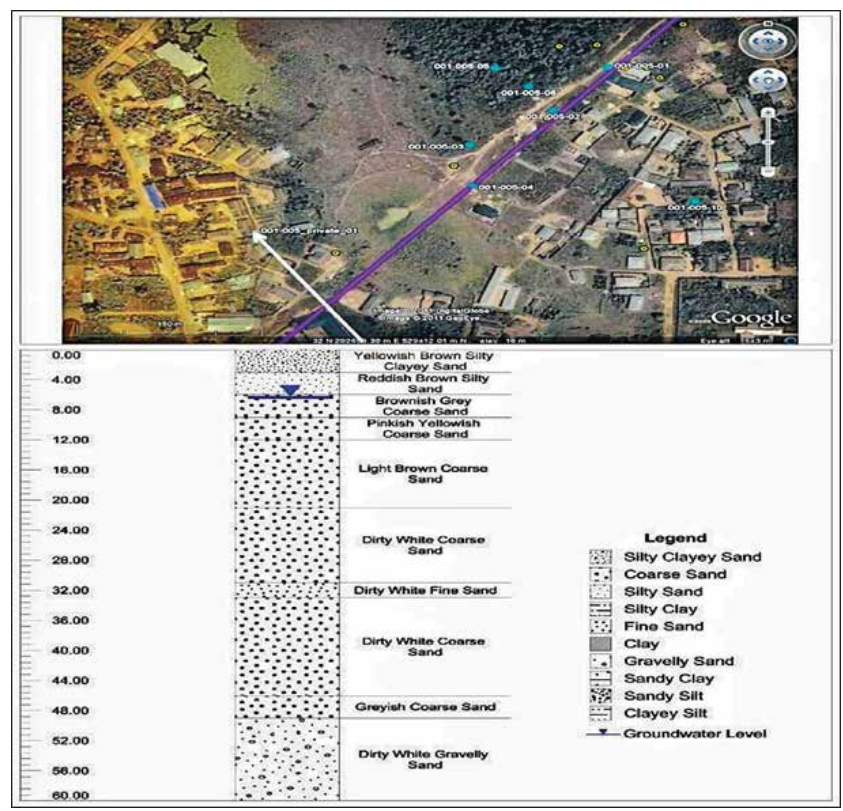

Figure 2: Soil logs from Nsioken Agbi Ogale, Eleme L.G.A.

reason why it is very difficult to embark on, and enforce appropriate remediation procedures.

The structure of Practise Guide for investigation and remediation of contaminated land (PG) follows the stages of the contamination assessment and remediation process as summarized inflow chart in Figure 2 [6-15].

\section{Methodology (Decision Support System)}

The Decision Support System is designed by ranking the contaminants, soil type, cost, efficiency and duration of operation as shown in Table 1 [16-23]. The comparative evaluation of soil remediation techniques using decision support system comprising of contaminant type, cost, soil type (Table 2).

\section{Theoretical Application, Result and Discussion (A case study of Nsioken Agbi Ogale, Eleme L.G.A Ogoniland)}

The result of soil logs from Nsioken Agbi Ogale, Eleme is shown in Figure 2; Considering that the oil spills took place between 1986 and 1990, natural attenuation, or biodegradation of contaminants has not proven effective in reducing contaminant concentrations to safe levels in the affected area [5,24-33]. Another reason why natural attenuation has failed is the presence of silty clay or pure clay soil in some areas. Natural attenuation does not work well in fine grained soils [34-40].

Critically analysing Table 2 in relation to the soil log result of Nsioken Agbi Ogale between 0-4 m, the most suitable method is the combination of phyto-remediation and soil vapour extraction. Phytoremediation has to be applied first between 2 to 3 years. First, because of its effectiveness in all types of soil type, secondly, because of its cost effectiveness (Figure 2) [41-48].

After this period, the most effective, the relative cost effective method, that is soil vapour extraction should be used for at least one year to give the final recovery touch. SVE is emerging as the most frequently used technology. SVE not only promises good result in short time, but it is also cost effective [40,49-55].

Furthermore, between 4-6 m depth, methods effective in groundwater such as Air Sparging should be used in combination with SVE. SVE will take care of deficiencies evident in Air sparging such as inability to work where soil permeability is low and little lag in efficiency. Air sparging should be applied for six months before the application of SVE for one year [56-59].

\section{Conclusion and Recommendations}

The methods recommended in section 4 above should be applied in the study area. In summary, Air Sparging should be applied for six months between 4 to 6 metres whereas phyto-remediation should be applied for 2 years between $0-4 \mathrm{~m}$. After this period soil vapour extraction should be used for at least one year over the entire length of six metres. After the remediation, TPH value should be checked to make sure it is within the acceptable limit, if not the SVE should continue for another one year. Finally, Nigeria government should put

\begin{tabular}{|c|c|c|c|c|c|c|c|c|c|}
\hline \multicolumn{2}{|c|}{ Contamination } & \multicolumn{2}{|c|}{ Soil Type } & \multicolumn{2}{|c|}{ Cost } & \multicolumn{2}{|c|}{ Efficiency } & \multicolumn{2}{|c|}{ Duration } \\
\hline Type & Representation & Type & Representation & Range & US/Tonnes & Range & Rank & Range & Rank \\
\hline VOCS & $A$ & Fine clay & $A$ & $>150$ & $A$ & $>90 \%$ & $A$ & 1-6 months & A \\
\hline SVOCS & B & Medium clay & $\mathrm{B}$ & $75-150$ & B & $75-90 \%$ & B & $6-12$ months & B \\
\hline $\begin{array}{l}\text { Medium to heavy } \\
\text { hydrocarbons }\end{array}$ & $\mathrm{C}$ & Silty clay & C & $50-75$ & C & $50-75 \%$ & $\mathrm{C}$ & $1-2$ years & $\mathrm{C}$ \\
\hline & & Clay silt & $\mathrm{D}$ & $25-50$ & $\mathrm{D}$ & $<50 \%$ & $\mathrm{D}$ & $2-5$ years & $\mathrm{D}$ \\
\hline & & Silty sand & $E$ & 25 & $E$ & & & $>5$ years & $E$ \\
\hline & & Silt & $\mathrm{F}$ & $<10$ & $\mathrm{~F}$ & & & & \\
\hline & & Sandy clay & $G$ & & & & & & \\
\hline & & Sandy Silt & $\mathrm{H}$ & & & & & & \\
\hline & & Sand & $\mathrm{i}$ & & & & & & \\
\hline
\end{tabular}

Table 1: Decision support system for petroleum containment land. 
Citation: Emeka AE (2016) Theoretical Application of Decision Support System in Petroleum Contaminated Ogoniland in South-Southern Nigeria. J Pet Environ Biotechnol 7: 303. doi: 10.4172/2157-7463.1000303

Page 3 of 4

\begin{tabular}{|c|c|c|c|c|c|}
\hline Technique & Contaminant & Soil type & Cost & Efficiency & Duration \\
\hline Enhanced Bioremediation & $B \& C$ & $A-I$ & C-D & B & D-E \\
\hline Bioventing & $B \& C$ & $\mathrm{D}-\mathrm{F}$ & C-E & A & $A-B$ \\
\hline Natural Attenuation & $A \& B$ & F-I & Variable & $A-B$ & $E$ \\
\hline Phylo-remediation & $A, B \& C$ & Independent & D-E & C-D & D-E \\
\hline Air Sparing & $A \& B$ & F-I & C & $\mathrm{B}$ & $A$ \\
\hline Soil Vapour Extraction & $A \& B$ & $\mathrm{~F}-\mathrm{I}$ & C & A & $B-C$ \\
\hline Thermal Treatment & $A \& B$ & $A-I$ & $E-F$ & B & $A-B$ \\
\hline Soil Washing & $B \& C$ & F-I & A-B & $A$ & $A$ \\
\hline Incineration & $A, B \& C$ & $A-I$ & $\mathrm{E}-\mathrm{F}$ & B & A-B \\
\hline Thermal Desorption & $A \& B$ & A-F except C & C-E & $A$ & $A-B$ \\
\hline Excavation and Disposal & $A, B \& C$ & A-I & $A-B$ & $A$ & $A-B$ \\
\hline
\end{tabular}

Table 2: Comparative evaluation of soil remediation techniques.

up a strong legal and institutional framework to enforce remediation of petroleum contaminated land. Government should train adequate manpower that will take charge of the aforementioned institutions as well as pay them what is obtainable in multinational oil companies in order not to lose their services.

\section{References}

1. Sanchez-Narre M, Gilbert K, Sodja RS, Skeyer JP, Struss P, et al (2008) Intelligent environmental decision support system. Development in Integrated Environmental Assessment 3: 11-44.

2. Vegter JJ (2001) Sustainable contaminated land management: A risk-based land management approach. Land Contamination \& Reclamation 9: 95-100.

3. EEA (2007) The unseen threat to water quality: Diffused water pollution in England and wales report. European Environmental Agency.

4. Clarinet Association (2003) Sustainable management of contaminated land-An Overview.

5. UNEP (2012) Assessment of contaminated soil and groundwater in Ogoni south-south Nigeria. UNEP report.

6. Adams JA, Reddy KR (2003) Extent of benzene biodegradation in saturated soil column during air sparging. Ground Water Monitoring and Remediation 23: 85-94.

7. Alkorta I, Garbisu C (2001) Phytoremediation of organic contaminants in soils. See comment in PubMed Commons below Bioresour Technol 79: 273-276.

8. Alpaslan B, Yukselen MA (2002) Remediation of lead contaminated soils by stabilization/ solidification- water. Air and soil pollution 133: 253-263.

9. Asente-Dual DK (1996) Managing contaminated sites. Problem diagnosis and development of site remediation. Wiley, New York, NY.

10. Baker RS, Moore AT (2000) Optimizing the effectiveness of in-situ bioventing Pollution Engineering 32: 44-47.

11. Barter MA (1999) Phytoremediation-an overview. Journal of New England Water Environmental Association 33: 158-164

12. Bass DH, Hastings NA, Brown RA (2000) Performance of air sparging systems: a review of case studies. J Hazard Mater 72: 101-119.

13. Dambatta B, Javadi AA (2009) Risk based assessment and management of total petroleum hydrocarbon contamination in soil. 23rd European Conference on Operational research, Bonn, Germany.

14. Benner ML, Mohtar RH, Lee LS (2002) Factors affecting air sparging remediation system using field data and numerical simulations. Journal of Hazardous Material 95: 305-329.

15. Boire $P$ (1998) Air sparging bioremediation of petroleum hydrocarbon contaminated soils. Biorem Technologies Inc Water100.

16. Chu W (2003) Remediation of contaminated soils by surfactant-aided soil washing. Practice Periosical of Hazardous. Toxic and Radioactive Waste Management 7: 19-24

17. Chu W, Chan KH (2003) The mechanism of the surfactant-aided soil washing system for hydrophobic and partial hydrophobic organics. Science of the Total Environment 307: 83-92.
18. CPEO (1998) Thermal desorption. Center for Public Environmental Oversight 425, Market Street San Francisco, CA.

19. DENIX (1995) Natural attenuation for petroleum contaminated sites at Federal Facilities. Defense Environmental Network and Information Exchange.

20. Dermatas D, Mang X (2003) Utilization of flyash for stabilization/solidication of heavy metal contaminated soils. Engineering geology 70: 377-394.

21. Diele F, Notarnicola F, Sgura I (2002) Uniform air velocity field for a bioventing system design: Some numerical result. Int J Eng Sci 40: 1199-1210.

22. EPD (2011) Environmental Protection Department. The government of the Hong Kong Special Admin Region.

23. Erickson LE, Banks MK, Davis LC, Schivab AP, Muralidharan N, et al. (1999) Using vegetation to enhance In-Situ Bioremediation. Centre for Hazardous Substances Research, Kansas University. Manhattan KA.

24. ESEPA (1998a) Bioventing of the underground Storage Tank, US Environmenta Protection Agency. Publication\# EPA 510-B-95-007.

25. Feng D, Lorenzon L, Aldrich C, Mare PW (2001) Ex-situ diesel contaminated soil washing with mechanical methods. Mineral Engineering 14: 1093-1100.

26. Filler DM, Lindstorm JE, Braddock JF, Johnson RA, Nickalaski R (2001) Integral biopile components for successful bioremediation in the Arctic. Cold regions science and Technology 32: 143-156.

27. FRTR (1999d) Thermal desorption federal remediation technology roundtable. USEPA $401 \mathrm{M}$ Street SW Washington DC.

28. FRTR (1999) Slury phase biological treatment. Federal Remediation Technologies Round Table. USEPA 401 M Street SW Washington DC.

29. FRTR (1999b) Bioventing federal remediation technologies roundtable. USEPA $401 \mathrm{M}$ Street SW Washington DC.

30. FRTR (1999c) Biopiles federal remediation technologies roundtable. USEPA $401 \mathrm{M}$ street SW Washington DC.

31. GWRTAC (1996a) Phytoremediation groundwater remediation technologies analysis center six Avenue regional Enterprise Tower Pittsburgh PA.

32. GWRTAC (1996b) Technical documents-technical Overview reports Groundwater Remediation Technologies Analysis Center. 425 6th Avenue. Regional Enterprise Tower Pittsburgh PA.

33. Halmemies S, Grondahl S, Arffman M, Nenonen K, Tuhkamen T (2003) Vacuum extraction based response equipment for recovery of Fresh Fuel spills from soil. J Hazardous Material 97: 127-143.

34. Harper BM, Stiver WH, Zytner RG (2003) Non-equilibrium nonagueous phase liquid mass transfer model for soil vapour extraction system. J Environmental Engineering 129: 745-754.

35. Jørgensen KS, Puustinen J, Suortti AM (2000) Bioremediation of petroleum hydrocarbon-contaminated soil by composting in biopiles. Environ Pollut 107 245-254.

36. Khan FI, Husain T (2003) Evaluation of a petroleum hydrocarbon contaminated site for natural attenuation using 'RBMNA' methodology. Environmental Modeling and Software 18: 179-194.

37. Khan FI, Husain T (2002) Evaluation of contaminated sites using risk based 
Citation: Emeka AE (2016) Theoretical Application of Decision Support System in Petroleum Contaminated Ogoniland in South-Southern Nigeria. J Pet Environ Biotechnol 7: 303. doi: 10.4172/2157-7463.1000303

Page 4 of 4

monitored natural attenuation. Chemical engineering progress AICHE USA $34-44$

38. Khan FI, Husain T, Hejazi R (2004) An overview and analysis of site remediation technologies. See comment in PubMed Commons below J Environ Manage 71 95-122.

39. Li P, Sun T, Stagnitti F, Zhang C, Zhang H, et al. (2003) Field-scale bioremediation of soil contaminated with crude oil. Environmental Engineering Science 19: 277-289.

40. Mihopoulos PG, Suidan MT, Sayles GD, Kaskassian S (2002) Numerical modeling of oxygen exclusion experiments of anaerobic bioventing. J Contam Hydrol 58: 209-220.

41. Mihopoulos PG, Suidan MT, Sayles GD (2001) Complete remediation of PCE contaminated unsaturated soils by sequential anaerobic-aerobic bioventing. Water Sci Technol 43: 365-372.

42. Nyer EK (1996) In situ treatment technology. Lewis Publishers, Boca Raton, FL.

43. Pulford ID, Watson C (2003) Phytoremediation of heavy metal-contaminated land by trees-a review. Environ Int 29: 529-540.

44. RAAG (2000) Evaluation of risk based corrective action model remediation alternative assessment group, Memorial University of newfoundland St. John's NF, Canada.

45. Rai JPN, Singhal V (2003) Biogas production from water hyacinth and channel grass used from phytoremediation of industrial effluents. Bioresource Technology 86: 221-225.

46. Riser-Roberts E (1998) Bioremediation of petroleum contaminated sites CRC Press Raton FL.

47. Suffersan SS (1997) Remediation Engineering: Design concepts. Lewis Publishers, Boca Raton, FL.

48. Urum P, Pekdemir T, Gopur M (2003) Optimum conditions for washing of crude oil-contaminated soil with biosurfactant solutions. Process Safety and Environmental Protection: Transactions of the Institution of Chemical Engineers, part B 81: 203-209.

49. USEPA (1995a) How to evaluate alternative clean-up technologies for underground storage tank sites. Office of solid Waste and Emergency responses US Environmental Protection Agency Washington D.C.

50. USEPA (1996a) A citizens guide to natural attenuation. Office of solid waste and emergency response. US environmental protection agency publication \# EPA 542-F-96-015 Washington DC

51. USEPA (1996b) A citizen's guide to phytoremediation office of solid waste and emergency response, US Environmental Protection Agency. Washington DC.

52. USEPA (1998c) Soil vapour extraction (SVE) Office of the Underground Storage Tank, US Environmental Protection Agency.

53. USEPA (1998b) Biopiles, Office of the Underground Storage Tank, US Environmental Protection Agency.

54. USEPA (1996e) A citizen's guide to in-situ thermal desorption, Office of solid Waste and Emergency Response. US Environmental Protection-Publication \# EPA 542-F-96-005, Washington, DC.

55. USEPA (1996d) A citizen's guide to soil washing. Office of Solid Waste and Emergency Response, US Environmental Protection Agency Publication \#EPA 542-F-96-002, Washington D.C.

56. Vouillamoz J, Milke MW (2001) Effect of compost in phytoremediation of dieselcontaminated soils. Water Sci Technol 43: 291-295.

57. Wait ST, Thomas D (2003) The characterization of base oil recovered from the low temperature thermal desorption of drill cuttings. SPE/EPA Exploration and Production, Environmental Conference, Mar 10-12, San Antonio, TX - pp 151-158

58. Wiedemeier TH, Newell CJ, Rifai HS, Wilson Jl (1999) Natural attenuation of fuels and chlorinated solvents in the sub forces. Wiley, New York.

59. Zhan H, Park E (2002) Vapour flow to horizontal well in unsaturated zones. Soi Science Society of American Journal 66: 710-721. 